\title{
Non-invasive prediction of implantation window in controlled hyperstimulation cycles: Can the time from the menstrual day at embryo transfer to expected menstrual cycle give a clue?
}

\author{
Kontrollü hiperstimülasyon sikluslarda implantasyon \\ penceresinin non-invaziv tespiti: Embriyo transferi yapılan \\ menstürasyon günü ile beklenen menstürasyon siklusu \\ arasindaki zaman ipucu verir mi?
}

İlhan Şanverdi, Enis Özkaya, Tayfun Kutlu, Taylan Şenol, Munip Akalın, Eda Sayar Akalın, Yavuz Şahin, Ateş Karateke

Zeynep Kamil Women and Children's Health Training and Research Hospital, Clinic of Obstetrics and Gynecology, İstanbul, Turkey

\begin{abstract}
Objective: The aim of this study was to assess whether the time from the menstrual day at embryo transfer to expected menstrual cycle (TETEMC) is associated with the implantation in women with regular cycles or not.

Materials and Methods: Forty women with successful implantation and forty women without implantation with regular cycles were randomly selected from prospectively collected database of assisted reproductive technology clinic of Zeynep Kamil Women And Children's Health Training and Research Hospital. TETEMC was calculated for each case to assess relationship with the successful implantation.

Results: Comparison of groups revealed significant differences with regard to TETEMC and the menstrual period ( $<<0.05)$.

In ROC analyses both the TETEMC (AUC $=0.824, \mathrm{p}<0.001$ ) and the menstrual period (AUC=0.797, $\mathrm{p}<0.001$ ) were significant predictors for clinical pregnancy. Cut off value for the menstrual period was found to be 27.5 days with $82.6 \%$ sensitivity and $65 \%$ specificity. Cut off value for TETEMC was 11.5 days with $75 \%$ sensitivity and $63.2 \%$ specificity.

Conclusion: Longer menstrual cycle and the TETEMC seem to be associated with the implantation failure.

Keywords: Day of embryo transfer, artificial reproductive techniques, implantation

$\ddot{O} z$

Amaç: Bu çalışmanın amacı düzenli mens olan hastalarda embriyo transferi yapılan gün ile beklenen siklus günü arasındaki sürenin (TETEMC) implantasyon ile ilişkisini değerlendirmektir.

Gereç ve Yöntemler: Zeynep Kamil Eğitim ve Araştırma Hastanesi İnfertilite Kliniğine başvuran hastalar çalısmaya dahil edildi. Rastgele seçilmiş, adet siklusları düzenli ve başarılı implantasyon elde edilmiş 40 hasta ile, adet süreleri düzenli başarısız implantasyon elde edilen 40 hastanın tıbbi kayıtları prospektif olarak toplandı. Hastaların implantasyon ilişkisini değerlendirebilmek için TETEMC süreleri hesaplandı.

Bulgular: Gruplar karşılaştırıldığında menstrüel siklus günü ile TETEMC arasında anlamlı fark bulundu (p<0,05). ROC analizinde TETEMC (AUC=0,824, p<0,001) ve menstrüel gün (AUC=0,797, p<0,001) klinik gebeliğin anlamlı belirteçleri olarak bulundu. Menstrüel gün için cut off değeri hesaplandığında 27,5 gün için sensitivite $\% 82,6$ spesifite $\% 65$ bulundu. TETEMC için cut off değer $\% 75$ sensitivite ve $\% 63,2$ spesifite ile 11,5 gün bulundu.

Sonuç: Uzun menstrüel siklus ile TETEMC implantasyon başarısızlı̆̆ı ile ilişkili görünmektedir.

Anahtar Kelimeler: Embriyo transfer günü, yardımcı üreme teknikleri, implantasyon
\end{abstract}

Address for Correspondence/Yazışma Adresi: Enis Özkaya, MD,

Zeynep Kamil Women and Children's Health Training and Research Hospital, Clinic of Obstetrics and Gynecology, İstanbul, Turkey

Phone: +90 5054742459 E-mail: enozkaya1979@gmail.com

Received/Geliș Tarihi: 21.03.2016 Accepted/Kabul Tarihi: 06.08.2016

(CTurkish Journal of Obstetrics and Gynecology, Published by Galenos Publishing House.

This article is distributed under the terms of the "Creative Commons Attribution NonCommercial 4.0 International Licence (CC BY-NC 4.0)". 


\section{Introduction}

Window of implantation is defined as the period of an optimal synchronization between the embryo and the endometrium. In physiological menstrual cycles, this period corresponds to the menstrual days of 21-24 days in a women with regular 28 days of cycles. In other words, implantation can be achieved in a period of 4-7 days to next expected cycle. This period of implantation is determined by the sensitive balanced stimulation of steroids hormones of estrogen and progesterone secreted through the cycle(1-3). However; in stimulated cycles, it was reported that endometrial maturation can be 3 days early compared to unstimulated cycles(4). In the current practice, window of implantation was tried to be predicted indirectly by endometrial thickness measurement. Cut off value for the endometrial thickness for successful implantation was reported to be $6 \mathrm{~mm}^{(5-7)}$. However according to our experience and the reports from literature, $50 \%$ of patients with optimal endometrial thickness and high grade embryos fail to conceive. Endometrial receptivity is determined by several factors and these factors were reported to be under the effect of gonadal hormones, so it is expected to see a change in receptive period with changing endocrine milieu. In ovarian stimulation cycles gonadal hormones are secreted in high levels compared to physiological states so this may change the implantation period. The aim of this study was to assess whether the time from the menstrual day at embryo transfer to expected menstrual cycle (TETEMC) is associated with the implantation in women with regular cycles or not.

\section{Materials and Methods}

Between January 2014 and December 2015, women with regular cycles who underwent artificial reproduction in the in vitro fertilization (IVF)/intra-cytoplasmic sperm injection unit of Zeynep Kamil Women and Children's Health Training and Research Hospital were recruited from prospectively collected database. Age, body mass index matched groups of women with $(n=40)$ and without $(n=40)$ successful implantation after grade 1 embryo transfer were randomly selected and compared in terms of some demographic and clinical characteristics including TETEMC, endometrial thickness at embryo transfer and duration of regular cycles. Embryo grading was determined according to the review by Alpha Scientists in Reproductive Medicine and European Society of Reproduction and Embryology Special Interest Group of Embryology(8). All the participants had regular menstrual cycles, as well as normal serum prolactin levels and without hormone treatment within three months. The patients' ages ranged from 24 to 39 years. In all patients artificial reproductive techniques (ART) were indicated for unexplained infertility. Unexplained infertility was diagnosed when a patient was infertile with normal ovulatory and tubal functions along with a normal sperm count for her partner. These were determined by the regularity of menstrual cycles, hysterosalphingography, and semen analysis, respectively. Women with low ovarian reserve, irregular cycles, polycystic ovarian syndrome and the endometriosis were excluded from the study.

Antagonist protocol was used in all cases; on the second day of the menstrual cycle, recombinant follicle stimulating hormone $(\mathrm{rFSH})$, depending on patient's response, were administered and follicular growth was monitored using transvaginal sonography. The dosage of $\mathrm{rFSH}$ was adjusted from day 5 of stimulation according to the ovarian response. Antagonist Cetrorelix (MerkSereno, Geneva, Switzerland) $0.25 \mathrm{mg}$ /day was administered when the follicular size was $12 \mathrm{~mm}$. After the follicular size reached $>18 \mathrm{~mm}$, recombinant human chorionic gonadotropin (HCG) $250 \mu \mathrm{g}$ was administered, and follicular puncture was performed after 34-36 hours. Then we started the application of $8 \%$ vaginal progesterone gel twice/daily. Serum HCG level was measured two weeks later, and if serum HCG level was more than or equal to normal level, we performed ultrasonography to detect the pulse of fetus to confirm clinical pregnancy. TETEMC was divided into 4 groups as group 1: 0-4 days, group 2: 5-8 days, group 3: 9-13 days, group 4: >14 days. Groups were compared in terms of successful implantation.

TETEMC was the number of days from the day at embryo transfer to the first day of expected menstrual cycle determined from regular cycles.

\section{Statistical Analyses}

Data was analyzed using SPSS 15.0 for Windows. Pearson's correlation analysis or Spearman's correlation analysis was performed to assess the correlation between different variables and ovarian response and the correlation between one variable and another as appropriate. Student t test was used to compare continuous variables between the groups. Multivariate regression analyses were used to assess the adjusted associations. Receiver operating characteristic (ROC) analyses were used to assess the predictive value of the test and to calculate sensitivity and specificity. $\mathrm{P}$ value $<0.05$ was accepted to be statistically significant.

\section{Results}

\section{Group comparisons}

Comparison of groups with and without successful implantation revealed significant differences in between groups with regard to TETEMC and menstrual period (Table 1). There were 11 three day embryo transfers where as the number of five day embryo transfer was 69 ( $p>0.05)$.

\section{Correlation analyses}

Correlation analyses revealed significant correlations in between the successful implantation and TETEMC, duration of menstruation and the age (Table 2).

\section{Multivariate regression analyses}

Multivariate analysis revealed significant association in between the TETEMC and clinical pregnancy after adjustment for age and the duration of menstruation (Table 3). 


\section{Receiver operating characteristic analyses}

In ROC analyses both the TETEMC (AUC=0.824, $\mathrm{p}<0.001$ ) and the menstrual period (AUC $=0.797, \mathrm{p}<0.001$, Figure 1) were significant predictors for clinical pregnancy. Cut off value for the menstrual cycle was found to be 27.5 days with $82.6 \%$ sensitivity and $65 \%$ specificity. Cut off value for TETEMC was 11.5 with $75 \%$ sensitivity and $63.2 \%$ specificity.

\section{Subgroup comparisons}

Comparison of groups with TETEMC $\leq 11.5$ and $>11.5$ days for successful implantation revealed a significant difference indicating higher rates in group with TETEMC $\leq 11.5$ ( $75.9 \%$ vs. $35.3 \%$, $\mathrm{p}<0.05$, Table 4). Comparison of groups with duration from the menstrual period $\leq 27.5$ and $>28$ days for successful implantation revealed a significant difference indicating higher rates in group with menstrual period $\leq 27.5$ (82.6\% vs. $36.8 \%$, p $<0.05$, Table 5 ).

Table 1. Comparison of some demographic and clinical characteristics between groups

\begin{tabular}{|c|c|c|c|c|c|}
\hline & Implantation & $\mathrm{n}$ & Mean & $\begin{array}{l}\text { Standard } \\
\text { deviation }\end{array}$ & \\
\hline \multirow[t]{2}{*}{ Age (years) } & Negative & 40 & 31.88 & 4.783 & \\
\hline & Positive & 40 & 29.83 & 4.050 & NS \\
\hline \multirow[t]{2}{*}{ Antral follicle count } & Negative & 40 & 13.03 & 5.785 & \\
\hline & Positive & 40 & 13.03 & 4.886 & NS \\
\hline \multirow[t]{2}{*}{ Peak estradiol (pg/mL) } & Negative & 40 & 1415.60 & 1.006 .976 & \\
\hline & Positive & 40 & 1519.25 & 790.780 & NS \\
\hline \multirow[t]{2}{*}{ Duration of stimulation } & Negative & 40 & 9.88 & 1.786 & \\
\hline & Positive & 40 & 10.50 & 1.725 & NS \\
\hline \multirow[t]{2}{*}{ Menstrual day at ET } & Negative & 40 & 15.73 & 1.754 & \\
\hline & Positive & 40 & 16.35 & 1.875 & NS \\
\hline \multirow[t]{2}{*}{ Of oocytes } & Negative & 40 & 8.33 & 5.385 & \\
\hline & Positive & 40 & 7.65 & 3.759 & NS \\
\hline \multirow[t]{2}{*}{ Total gonadotropin dose } & Negative & 40 & 2163.75 & 1.138 .191 & \\
\hline & Positive & 40 & 2366.88 & 1.111 .729 & NS \\
\hline \multirow[t]{2}{*}{ Initial dose } & Negative & 40 & 253.13 & 90.968 & \\
\hline & Positive & 40 & 246.25 & 78.762 & NS \\
\hline \multirow[t]{2}{*}{ Of embryos } & Negative & 40 & 4.5 & 3.4 & \\
\hline & Positive & 40 & 3.7 & 2.05 & NS \\
\hline \multirow[t]{2}{*}{ FSH U/mL } & Negative & 39 & 6.3 & 2.6 & \\
\hline & Positive & 40 & 5.7 & 2.1 & NS \\
\hline \multirow[t]{2}{*}{ Estradiol pg/mL } & Negative & 40 & 45.6 & 26.4 & \\
\hline & Positive & 40 & 45.5 & 20.8 & NS \\
\hline \multirow[t]{2}{*}{$\mathrm{AMH}(\mathrm{ng} / \mathrm{mL})$} & Negative & 10 & 5.6 & 5.1 & \\
\hline & Positive & 10 & 2 & 1.8 & NS \\
\hline \multirow[t]{2}{*}{ End line transfer (mm) } & Negative & 24 & 10 & 2.5 & \\
\hline & Positive & 28 & 9.4 & 1.8 & NS \\
\hline \multirow[t]{2}{*}{ TETEMC (days) } & Negative & 40 & 13.5 & 2.6 & \\
\hline & Positive & 40 & 10.6 & 2.2 & $<0.001$ \\
\hline \multirow[t]{2}{*}{ Menstrual period (days) } & Negative & 40 & 29.30 & 2.989 & \\
\hline & Positive & 40 & 26.95 & 1.753 & $<0.001$ \\
\hline
\end{tabular}

TETEMC: Transfer to expected menstrual cycle, NS: Non significant, AMH: Anti mullerian hormone, FSH: Follicle stimulating hormone, ET: Embryo transfer 
Comparison of successful implantation among the group with 4 different TETEMC revealed 100\% implantation rate in group with TETEMC $\leq 8$ days (Table 6).

\section{Discussion}

In this study, we tried to assess the effect of menstrual day at embryo transfer on the implantation rates in ovarian stimulation

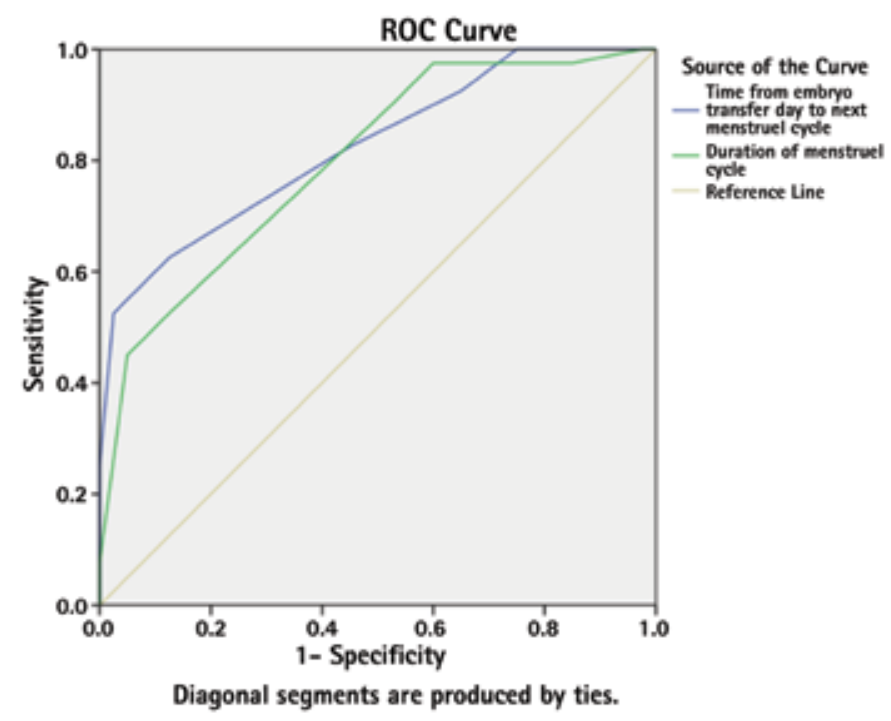

Figure 1. Receiver operating characteristic curve of transfer to expected menstrual cycle and menstrual period to predict implantation

ROC: Receiver operating characteristic

Table 2. Summary of correlation analyses between successful implantation and some variables

\begin{tabular}{|lllll|}
\hline Implantation & \multicolumn{1}{c}{ TETEMC } & $\begin{array}{l}\text { Menstrual } \\
\text { period }\end{array}$ & Age \\
\hline & $\begin{array}{l}\text { Correlation } \\
\text { coefficient } \\
\text { Significant } \\
\text { (2-tailed) }\end{array}$ & $-0.569^{* *}$ & $-0.534^{* *}$ & $-0.220^{*}$ \\
\hline $\mathrm{N}$ & 80 & 0.000 & 0.050 \\
\hline TETEMC: Transfer to expected menstrual cycle & & 80 & 80 \\
\hline
\end{tabular}

Table 3. Multivariate regression analyses for successful implantation

\begin{tabular}{|c|c|c|c|}
\hline & $\begin{array}{l}\text { Standardized } \\
\text { coefficients } \\
\text { Beta }\end{array}$ & $\mathrm{t}$ & Significant \\
\hline (Constant) & & 3.649 & 0.000 \\
\hline Age & -0.176 & -1.825 & 0.072 \\
\hline Menstrual period & -0.089 & -0.574 & 0.568 \\
\hline TETEMC & -0.435 & -2.800 & 0.006 \\
\hline
\end{tabular}

TETEMC: Transfer to expected menstrual cycle cycles. Our data revealed an early maturation of endometrium, however more sooner transfers especially 11.5 days before the next expected menstruation was associated with unsuccessful implantation with $75 \%$ sensitivity and $63.2 \%$ specificity. Besides estrogen and the progesterone, gonadotropin-releasing hormone $(\mathrm{GnRH})$ receptors were shown in extra pituitary tissue including the endometrium(9-11), studies reported the presence of GnRH mRNA gene expression in the endometrium throughout the menstrual cycle, with a significant increase in the secretory phase. These data indicate the possible physiological role of GnRH in the early stages of implantation via paracrine/ autocrine pathways. Due to this physiological effect, clinicians have become suspicious for the possible negative effect of $\mathrm{GnRH}$ antagonists in combination with gonadotropin on the assisted reproductive technology success $(12,13)$. Some evidence showed detrimental effects of GnRH antagonist that may interfere with the embryo implantation. Consequently(14), high dosages of GnRH antagonist ( 1 or $2 \mathrm{mg}$ once daily) were found to be associated with low implantation rate (8.8 and $1.5 \%$, respectively) in fresh cycles. Due to this data, in order to prevent ovarian hyper stimulation syndrome and for more receptive endometrium, freeze all policies were introduced and the review on this issue indicated reduced risk of ovarian hyper stimulation syndrome and improved outcomes with frozen embryo transfer(15).

Reduced implantation rates in IVF cycles were shown in some studies compared to natural ones(16), however, there is still some controversy regarding this issue. A large retrospective analysis, showed similar implantation rates between donor and recipient IVF patients(17).

In IVF cycles, the day of oocyte retrieval was thought to be the equivalent to day 14 in a natural cycle in women with 28 days regular cycles $(18,19)$. However, in ovarian stimulation cycles, an advanced endometrial maturation has been shown in some studies, this advancement was reported to be around $2 \pm 4$ days $(20)$ and seen in $45.5 \%(21)$ of cycles. As a consequence, an early and increased progesterone concentrations were blamed for early secretory transformation(22) and followed by midluteal glandular maturation arrest ${ }^{(23)}$. High serum estradiol concentrations in stimulated cycles were also thought to result in glandular \pm stromal dyssynchrony that may interfere with the endometrial receptivity (24). Another data showed the direct effect of HCG that might lead to the advanced endometrial maturation $(25,26)$. Finally, studies showed that ovarian stimulation changed the luteal phase endometrial development. Luteal phase support was thought to significantly improve clinical outcomes in in-vitro fertilization cycles by the correction of these detrimental effects of ovulation induction(27). There is a consensus on the detrimental effect of ovarian stimulation on the endometrial receptivity and some measures have been introduced to overcome this issue like luteal phase support however, we hypothesized that despite advanced endometrial maturation, earlier transfers may be the main problem that lead 
to failed implantation, therefore timing of embryo transfer may be the cornerstone of this problem.

Study assessed the histological features of endometrium both at the 6th day after luteinising hormone (LH) surge and the 10 days after LH surge. Study revealed similar histological features with regard to endometrial maturation(28), in another study, pinopodes were observed at 20th day of menstruation and indicated period of implantation window started to open at days of 22-23 in women with 28 day regular cycles(29), as we mentioned above there is two to four days maturation advancement in stimulated cycles. Our data also showed some advancement in endometrial maturation but more sooner embryo transfers failed to implant. Significant predictive value of longer menstrual cycles also confirm this argument which increase possibility of high TETEMC.

A cochrane review on the comparison of ART success between the cases with two different embryo transfer days revealed significant difference in live birth rates in favour of blastocyst transfer (day 5 to 6) compared to cleavage stage transfer (day 2 to 3)(30). This data supports our arguments that three days delay in timing of embryo transfer seem to increase success rate. Recently published well designed study showed a suboptimal endometrial development in ART cycles, and indicated a altered regulation of specific endometrial receptors compared to the the natural cycle. Similar to our end point authors concluded to modify ovarian stimulation not only to yield the optimal

Table 4. Comparison of implantation rates between groups with high and low transfer to expected menstrual cycle

\begin{tabular}{|c|c|c|c|c|c|}
\hline & & & \multicolumn{2}{|c|}{ Implantation } & \multirow[t]{2}{*}{ Tota } \\
\hline & & & Negative & Positive & \\
\hline \multirow{4}{*}{ TETEMC (days) } & $\leq 11.5$ & Count & 7 & 22 & 29 \\
\hline & & $\%$ within luteal eleven point five & $24.1 \%$ & $75.9 \%$ & $100.0 \%$ \\
\hline & $>11.5$ & Count & 33 & 18 & 51 \\
\hline & & $\%$ within luteal eleven point five & $64.7 \%$ & $35.3 \%$ & $100.0 \%$ \\
\hline \multirow[t]{2}{*}{ Total } & & Count & 40 & 40 & 80 \\
\hline & & $\%$ within luteal eleven point five & $50.0 \%$ & $50.0 \%$ & $100.0 \%$ \\
\hline
\end{tabular}

TETEMC: Transfer to expected menstrual cycle

Table 5. Comparison of implantation rates between groups with long and short menstrual period

\begin{tabular}{|c|c|c|c|c|}
\hline & & \multicolumn{2}{|c|}{ Implantation } & Total \\
\hline \multirow[t]{3}{*}{ Menstrual period } & $\leq 27.5$ & 4 & 19 & 23 \\
\hline & & $17.4 \%$ & $82.6 \%$ & $100.0 \%$ \\
\hline & $>27.5$ & 36 & 21 & 57 \\
\hline \multirow[t]{2}{*}{ Total } & & 40 & 40 & 80 \\
\hline & & $50.0 \%$ & $50.0 \%$ & $100.0 \%$ \\
\hline
\end{tabular}

Table 6. Comparison of implantation rates among groups with different transfer to expected menstrual cycle intervals

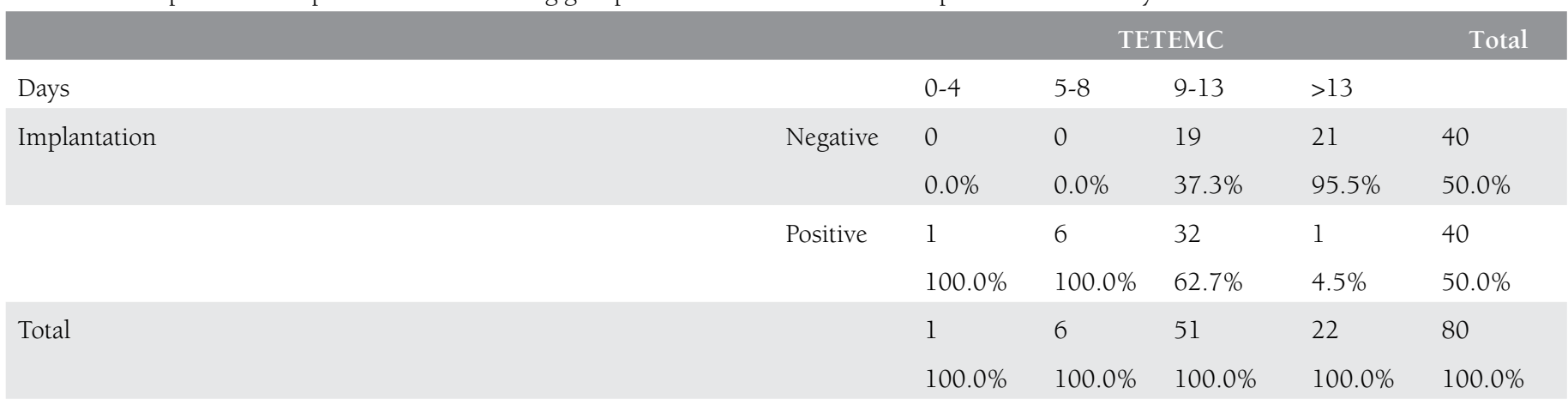

TETEMC: Transfer to expected menstrual cycle 
number of oocytes, but also to achieve serum hormonal levels that promote an optimal endometrial development and better pregnancy outcomes with fresh cycles. In addition to this study proposed cancellation of fresh embryo transfer and vitrification of embryos and postponing the transfer to more suitable endometrial development such as reached during natural cycles or controlled endometrial maturation(31). Our data showed that TETEMC lower than eight days resulted in $100 \%$ implantation where as there were $62.7 \%$ successful implantation in groups with TETEMC between the 9-13 days. The rate was $4.5 \%$ in group with TETEMC $>13$ days, we thought that this group of cases may be the appropriate candidates for freeze all policy.

Expression of HOXA10 varies in the human endometrium throughout the menstrual cycle, rising dramatically in the luteal phase at the time of implantation(32). This pattern of expression suggests a role for HOXA10 in the process of cyclic endometrial development and endometrial receptivity.

We thought that there is a sensitive gene expression regulation during menstrual cycle that determines the duration of menstruation and the time of implantation window, with ovarian stimulation, it seems that this regulated gene expression is not easily adapt this new microenvironment, previous study indicated the minimum period required to achieve a new level is directly proportional to product half-lives because rates of decay control the ratio between the rate of synthesis and the concentration of gene products at steady state(33).

Endometrial receptivity array have recently been introduced to assess the endometrial receptivity via genetic evaluation(34), however this test needs invasive procedures.

\section{Conclusion}

In conclusion, longer menstrual cycle and the TETEMC seem to be associated with the implantation failure. According to this data it is reasonable to take account the duration of regular menstruation and TETEMC to determine the candidates for freeze all policy.

\section{Ethics}

Ethics Committee Approval: The study were approved by Zeynep Kamil Training and Research Hospital Local Ethics Committee, Informed Consent: Study was approved by institutional review board and inform constent was obtained by each participant.

Peer-review: Internal peer-reviewed.

\section{Authorship Contributions}

Surgical and Medical Practices: Ilthan Şanverdi, Enis Özkaya, Tayfun Kutlu, Yavuz Şahin, Concept: Enis Özkaya, Tayfun Kutlu, Ateş Karateke, Design: Enis Özkaya, İthan Şanverdi, Data Collection or Processing: Taylan Şenol, Munip Akalın, Eda Sayar Akalın, Analysis or Interpretation: Enis Özkaya, Taylan Şenol, Literature Search: Enis Özkaya, Taylan Şenol, Writing: Enis Özkaya, Taylan Şenol. Conflict of Interest: No conflict of interest was declared by the authors.
Financial Disclosure: The authors declared that this study has received no financial support.

\section{References}

1. Navot D, Scott RT, Droesch K, Veeck LL, Liu HC, Rosenwaks Z. The window of embryo transfer and the efficiency of human conception in vitro. Fertil Steril 1991;55:114-8.

2. Wilcox AJ, Baird DD, Weinberg CR. Time of implantation of the conceptus and loss of pregnancy. N Engl J Med 1999;340:1796-9.

3. Prapas Y, Prapas N, Jones EE, Duleba AJ, Olive DL, Chatziparasidou A, et al. The window for embryo transfer in oocyte donation cycles depends on the duration of progesterone therapy. Hum Reprod 1998;13:720-3.

4. Saadat P, Boostanfar R, Slater CC, Tourgeman DE, Stanczyk FZ, Paulson RJ. Accelerated endometrial maturation in the luteal phase of cycles utilizing controlled ovarian hyperstimulation: impact of gonadotropin-releasing hormone agonists versus antagonists. Fertil Steril 2004;82:167-71.

5. Gonen Y, Casper RF. Prediction of implantation by the sonographic appearance of the endometrium during controlled ovarian stimulation for in vitro fertilization (IVF). J In Vitro Fert Embryo Transf 1990; 7:146-52.

6. Gonen Y, Casper RF, Jacobson W, Blankier J. Endometrial thickness and growth during ovarian stimulation: a possible predictor of implantation in in vitro fertilization. Fertil Steril 1989;52:446-50.

7. Coulam CB, Bustillo M, Soenksen DM, Britten S. Ultrasonographic predictors of implantation after assisted reproduction. Fertil Steril 1994;62:1004-10.

8. Alpha Scientists in Reproductive M, Embryology ESIGo. The Istanbul consensus workshop on embryo assessment: proceedings of an expert meeting. Hum Reprod 2011;26:1270-83.

9. Hernandez ER. Embryo implantation and GnRH antagonists: embryo implantation: the Rubicon for GnRH antagonists. Hum Reprod 2000;15:1211-6.

10. Dong KW, Marcelin K, Hsu MI, Chiang CM, Hoffman G, Roberts JL. Expression of gonadotropin-releasing hormone (GnRH) gene in human uterine endometrial tissue. Mol Hum Reprod 1998;4:893-8.

11. Raga F, Casan EM, Kruessel JS, Wen Y, Huang HY, Nezhat C, et al. Quantitative gonadotropin-releasing hormone gene expression and immunohistochemical localization in human endometrium throughout the menstrual cycle. Biol Reprod 1998;59:661-9.

12. Fauser BC, Devroey P. Why is the clinical acceptance of gonadotropin-releasing hormone antagonist cotreatment during ovarian hyperstimulation for in vitro fertilization so slow? Fertil Steril 2005;83:1607-11.

13. Griesinger G, Felberbaum R, Diedrich K. GnRH antagonists in ovarian stimulation: a treatment regimen of clinicians' second choice? Data from the German national IVF registry. Hum Reprod 2005;20:2373-5.

14. A double-blind, randomized, dose-finding study to assess the efficacy of the gonadotrophin-releasing hormone antagonist ganirelix (Org 37462) to prevent premature luteinizing hormone surges in women undergoing ovarian stimulation with recombinant follicle stimulating hormone (Puregon). The ganirelix dose-finding study group. Hum Reprod 1998;13:3023-31.

15. Evans J, Hannan NJ, Edgell TA, Vollenhoven BJ, Lutjen PJ, Osianlis T, et al. Fresh versus frozen embryo transfer: backing clinical decisions with scientific and clinical evidence. Hum Reprod Update 2014;20:808-21.

16. Smacklon N, Fauser BC. Regulation of follicle development and novel approaches to ovarian stimulation for IVF. Hum Reprod Update 2000;6:307-12. 
17. Levi AJ, Drews MR, Bergh PA, Miller BT, Scott RT. Controlled ovarian hyperstimulation does not adversely affect endometrial receptivity in in vitro fertilization cycles. Fertil Steril 2001;76:670-4.

18. Develioglu OH, Hsiu JG, Nikas G, Toner JP, Oehninger S, Jones HW. Jr. Endometrial estrogen and progesterone receptor and pinopode expression in stimulated cycles of oocyte donors. Fertil Steril 1999;71:1040-7.

19. Creus M, Calafell JM, Civico S, Fabregues F, Carmona F, Vanrell JA, et al. Materno-fetal immunogenetic disparity: the biological basis for in vitro fertilization treatment in patients with unexplained recurrent abortion? Am J Reprod Immunol 2003;50:420-6.

20. Ubaldi F, Bourgain C, Tournaye H, Smitz J, Van Steirteghem A, Devroey P. Endometrial evaluation by aspiration biopsy on the day of oocyte retrieval in the embryo transfer cycles in patients with serum progesterone rise during the follicular phase. Fertil Steril 1997;67:521-6.

21. Lass A, Peat D, Avery S, Brinsden P. Histological evaluation of endometrium on the day of oocyte retrieval after gonadotrophinreleasing hormone agonist-follicle stimulating hormone ovulation induction for in-vitro fertilization. Hum Reprod 1998;13:3203-5.

22. Fanchin R, de Ziegler D, Castracane VD, Taieb J, Olivennes F, Frydman R. Physiopathology of premature progesterone elevation. Fertil Steril 1995;64:796-801

23. Ezra Y, Simon A, Sherman Y, Benshushan A, Younis JS, Laufer N. The effect of progesterone administration in the follicular phase of an artificial cycle on endometrial morphology: a model of premature luteinization. Fertil Steril 1994;62:108-12.

24. Basir GS, O WS, Ng EH, Ho PC. Morphometric analysis of periimplantation endometrium in patients having excessively high oestradiol concentrations after ovarian stimulation. Hum Reprod 2001;16:435-40.

25. Tang B, Gurpide E. Direct effect of gonadotropins on decidualization of human endometrial stroma cells. J Steroid Biochem Mol Biol 1993;47:115-21.
26. Han SW, Lei ZM, Rao CV. Treatment of human endometrial stromal cells with chorionic gonadotropin promotes their morphological and functional differentiation into decidua. Mol Cell Endocrinol 1999;147:7-16.

27. DiLuigi AJ, Nulsen JC. Effects of gonadotropin-releasing hormone agonists and antagonists on luteal function. Curr Opin Obstet Gynecol 2007;19:258-65.

28. Haddad Filho J, Cedenho AP, de Freitas V. Correlation between endometrial dating of luteal phase days 6 and 10 of the same menstrual cycle. Sao Paulo Med J 1998;116:1734-7.

29. Acosta AA, Elberger L, Borghi M, Calamera JC, Chemes H, Doncel GF, et al. Endometrial dating and determination of the window of implantation in healthy fertile women. Fertil Steril 2000;73:78898.

30. Glujovsky D, Blake D, Farquhar C, Bardach A. Cleavage stage versus blastocyst stage embryo transfer in assisted reproductive technology. Cochrane Database Syst Rev 2012:CD002118.

31. Detti L, Uhlmann RA, Fletcher NM, Diamond MP, Saed GM. Endometrial signaling pathways during ovarian stimulation for assisted reproduction technology. Fertil Steril 2013;100:88994.

32. Bagot CN, Kliman HJ, Taylor HS. Maternal HoxalO is required for pinopod formation in the development of mouse uterine receptivity to embryo implantation. Dev Dyn 2001;222:538-44.

33. Hargrove JL, Hulsey MG, Beale EG. The kinetics of mammalian gene expression. Bioessays 1991;13:667-74.

34. Mahajan N. Endometrial receptivity array: Clinical application. J Hum Reprod Sci 2015;8:121-9. 